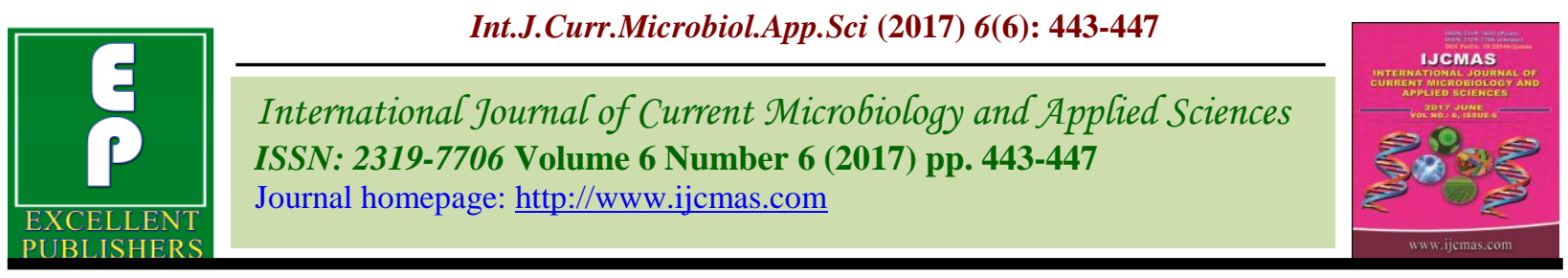

Original Research Article https://doi.org/10.20546/ijcmas.2017.606.051

\title{
Seasonal Variations in Physico-Chemical Characteristics of Champavathi Estuary, East Coast of India
}

\author{
R. Kurma Rao and K. Ramesh Babu* \\ Department of Marine Living Resources, College of Science and Technology, \\ Andhra University, Visakhapatnam-530 003, Andhra Pradesh, India \\ *Corresponding author
}

\section{A B S T R A C T}

Keywords

Physico-chemical parameters, Champavathi estuary, $\mathrm{pH}$, Salinity and Temperature.

\section{Article Info}

Accepted: 05 May 2017 Available Online: 10 June 2017
The seasonal variations of physico-chemical parameters were studied during January 2009 to December 2010 in the Champavathi estuary (Lat. $18^{\circ} 01^{\prime} \mathrm{N}$ Long. $\left.83^{\circ} 56^{\prime} \mathrm{E}\right)$ Northeast coast of India. The atmospheric and water temperature ranged from $26.3 \pm 1.42$ to $33.2 \pm 1.66^{\circ} \mathrm{C}$ and $23.2 \pm 2.89$ and $29.6 \pm 0.85^{\circ} \mathrm{C}$ respectively. The $\mathrm{pH}$ ranged between $7.8 \pm 0.65$ and $9.1 \pm 0.77$. The DO was ranged from $3.05 \pm 0.73$ to $8.94 \pm 0.97 \mathrm{ml} / \mathrm{l}$. Salinity fluctuated between $16.62 \pm 1.08 \%$ and $30.38 \pm 1.63 \%$. The rainfall was ranged between $5.5 \pm 0.58$ and $293.0 \pm 0.67$. The transparency was fluctuated between $0.31 \pm 0.12$ and $0.75 \pm 0.37$.

\section{Introduction}

Estuary is a specialized type of coastal body which is semi-enclosed, it has provision to connect open sea as well as fresh water bodies. Estuarine ecosystems are highly productive and dynamic in nature (Pillay et al., 2003). Estuarine processes vary in a systematic manner within tidal cycle (semidiurnal, diurnal), weather cycles (seasonal and inter annual cycles) (Dyer, 1986).

The environmental conditions such as topography, water movement and stratification, salinity, oxygen, temperature and various nutrients characterizing particular water mass determine the composition of its biota. Several reports are available on the physico-chemical features of Indian estuaries (Rajasegar, 2003; Balasubramanian and Kannan, 2005; Ajithkumar et al., 2006; Asha and Diwakar, 2007; Ashok Prabu et al., 2008; Saravanakumar et al., 2008; Gowda et al., 2009; Gadhia et al., 2012; Pravat Ranjan Dixit et al., 2013; Arumugam and Sugirtha P. Kumar, 2014; Uma Maheswara Rao et al., 2015; Sobha Rani, 2016).

The current study was undertaken to assess the present status of water quality in Champavathi estuary with reference to physico-chemical characteristics of water. 


\section{Materials and Methods}

Physico-chemical parameters of the monthly samples of water from the Champavathi estuary were recorded from January 2009 to December 2010. Surface water samples were collected in plastic containers. Air and water temperatures were measured using thermometer. Salinity was measured using Atago Refractometer. Dissolved oxygen was analysed by Winkler's method and transparency by using Secchi disc. $\mathrm{pH}$ was measured by a calibrated $\mathrm{pH}$ pen $(\mathrm{pH}$ ep-3 model). The rainfall data was obtained from the meteorological station at the Andhra University Campus, Visakhapatnam.

\section{Champavati estuary}

The Champavati estuary is located between $18^{\circ} 01^{\prime} \mathrm{N}$ latitude and $83^{\circ} 56^{\prime} \mathrm{E}$ longitude. It extended an area of 78 hectares, and meet Bay of Bengal by a river opening with $150 \mathrm{~m}$ wide. Sea water enters into the opening during the rainy season. It receives fresh water from western side through the Konada village at Vizianagaram district, fresh water enters estuary over a period of 8 to 9 months in a year, and the salinities very low condition in the estuary. The salinity of the estuarine water ranges between 16.62 and 30.38 ppt during the different seasons.

The Champavati estuary is formed by the Champavati it is a small river which originates in the Eastern Ghats at an altitude of 1,200 meters above sea level near Andra village and flows towards east and meet the Bay of Bengal near the village Konada. The river passes through Gajapathinagaram, Nellimarla, Saripalli, Denkada, Palem and Natavalasa of Vizianagaram district.

The river has four main tributaries Eduvampula Gedda, Chitta Gedda, Pothula Gedda and Gadi Gedda. Due to limited rain fall $(5.5 \pm 0.58)$ during summer the water flow is less from upstream. Fresh water enters estuary over a period of 8 to 9 months in a year, due to the reason high saline conditions are recorded in the estuary. The basin has a drainage area of 1,410 square kilometers. This area is divided into Hilly terrain (Madugula hills), Vizianagaram and Coastal plains. The depth of estuary water is about 8 to 10 feet.

\section{Results and Discussion}

\section{Physico-chemical characters}

Physico-chemical parameters of Champavati estuary was analyzed and estimated (Table 1). The major parameters of transparency, $\mathrm{pH}$, temperature (atmospheric and water), salinity, dissolved oxygen and rain fall are taken for a period of two years in the present study

The atmospheric temperature varied from $26.3 \pm 1.42$ to $33.2 \pm 1.66^{\circ} \mathrm{C}$. In the present study the air temperature showed marked variation with respect to seasons. The surface water temperature ranged between $23.2 \pm 2.89$ and $29.6 \pm 0.85^{\circ} \mathrm{C}$ for the two years of study period.

It is evident from the present results that the surface water temperature is influenced by the several factors like fresh water influx, solar radiation intensity, evaporation and cooling and mix up with ebb and neritic water inflow from the adjoining water bodies (Govindasamy et al., 2000; Saravanakumar et al., 2008). The findings of the present investigation following the trends of observations reported elsewhere (Desai, 1992; Arthur, 2000; Saravanakumar et al., 2008; Arumugam et al., 2014).

The $\mathrm{pH}$ varied from $7.9 \pm 0.81$ to $9.1 \pm 0.63$ during 2009 and between $7.8 \pm 0.65$ and $9.1 \pm 0.77$ during 2010. There are several factors which are associated with fluctuations 
in $\mathrm{pH}$ values throughout the year, they are like removal of $\mathrm{CO}_{2}$ in photosynthesis process which is resulted through bicarbonate degradation, seawater dilution by influx of freshwater, reduction of salinity, temperature as well as organic matter decomposition (Upadhyay, 1988; Rajasegar, 2003; Saravanakumar et al., 2008 and Arumugam et al., 2014).

Table.1 Correlation coefficient matrix of physico-chemical parameters of Champavati estuary during the year 2009-2010

\begin{tabular}{|c|c|c|c|c|c|c|c|}
\hline & Transparency & $\mathrm{pH}$ & Atmos phere & Water & Salinity & D.O & Rainfall \\
\hline \multirow[t]{2}{*}{ Transparency } & 1 & -.143 & .010 & .203 & $.496^{*}$ & $-.628^{\star \star}$ & -.354 \\
\hline & & .505 & .963 & .342 & .014 & .001 & .090 \\
\hline \multirow[t]{2}{*}{$\mathrm{pH}$} & -.143 & 1 & .341 & .331 & $-.643^{* *}$ & $.594^{\star \star}$ & $.651^{* *}$ \\
\hline & .505 & & .103 & .115 & .001 & .002 & .001 \\
\hline \multirow[t]{2}{*}{ Atmosphere } & .010 & .341 & 1 & $.852^{\star *}$ & -.361 & .115 & $.529^{* *}$ \\
\hline & .963 & .103 & & .000 & .083 & .592 & .008 \\
\hline \multirow[t]{2}{*}{ Water } & .203 & .331 & $.852^{* *}$ & 1 & -.128 & -.119 & .245 \\
\hline & .342 & .115 & .000 & & .551 & .581 & .249 \\
\hline \multirow[t]{2}{*}{ Salinity } & $.496^{*}$ & $-.643^{\star \star}$ & -.361 & -.128 & 1 & $-.848^{* \star}$ & $-.904^{\star *}$ \\
\hline & .014 & .001 & .083 & .551 & & .000 & .000 \\
\hline \multirow[t]{2}{*}{ D.O } & $-.628^{* *}$ & $.594^{* *}$ & .115 & -.119 & $-.848^{* *}$ & 1 & $.758^{* *}$ \\
\hline & .001 & .002 & .592 & .581 & .000 & & .000 \\
\hline \multirow[t]{2}{*}{ Rainfall } & -.354 & $.651^{* *}$ & $.529^{\star *}$ & .245 & $-.904^{* *}$ & $.758^{\star *}$ & 1 \\
\hline & .090 & .001 & .008 & .249 & .000 & .000 & \\
\hline
\end{tabular}

Salinity fluctuated between $17.32 \pm 1.07$ and $30.38 \pm 1.63$ ppt during 2009 where as in the year 2010 it was $16.62 \pm 1.08-29.63 \pm 2.25$ ppt. The highest salinity of $30.38 \pm 1.63$ was recorded in May 2009 and the lowest of 17.32 \pm 1.07 ppt was recorded in August 2009 . In the year 2010, the maximum of salinity $(29.60 \pm 2.25 \mathrm{ppt})$ was observed in the month of April-2010 and minimum (16.62 \pm 1.08$)$ was observed in the month of August 2010 (Table 1). The variations in the salinity values resulted by the dilution and evaporation processes, hence it act as limiting factor for the distribution of living organisms and fauna in the coastal ecosystem (Balasubramanian and Kannan, 2005; Sridhar et al., 2006). The findings of the present study in agreement with the previous workers reported earlier by Sundaramanickam et al., 2008; Santhosh Kumar and Ashok Prabu, 2014).
The highest concentration of dissolved oxygen $\left(8.94 \pm 0.97 \mathrm{mg} \mathrm{l}^{-1}\right)$ was recorded in the month of August and lowest concentration of $3.51 \pm 0.72 \mathrm{mg} \mathrm{l}^{-1}$ was recorded in the month of May during 2009. Whereas in the year 2010, the lowest and highest concentration of dissolved oxygen was noticed $3.05 \pm 0.73$, $8.94 \pm 0.97 \mathrm{mg} \mathrm{l}^{-1}$ in the month of April and August-2010 respectively (Table 1). Higher wind velocity which is coupled with the heavy rainfall during mansoon season and possible fresh water mixing may lead to increase the dissolved oxygen content as suggested earlier by Das et al., (1997) and Arumugam et al., (2014).

In Champavati estuary the lowest and highest value of rainfall $11.3 \pm 1.36,242.9 \pm 3.21$ and $5.5 \pm 0.58,293.0 \pm 0.67$ was noticed, during the years 2009 and 2010 respectively (Table 1). Rainfall brings a prominent change in 
physico-chemical parameters of the marine and estuarine water bodies in tropical countries. In the present investigation the higher rainfall data was recorded in the monsoon months of July and August. Similar kind of rainfall data was reported by Saravanakumar et al., (2008) from mangroves of Kachchh-Gujarat.

At Champavti estuary the lowest value of transparency was $0.31 \pm 0.12$ and highest value of $0.75 \pm 0.37$ was observed in the year 2009, where as in the year 2010, the lowest value of $0.32 \pm 0.17$ and highest value of $0.71 \pm 0.16$ was observed (Table 1). Suspended particles absorb heat, which causes water temperature to increase and it holds less oxygen than cold water (Voluntary estuary monitoring manual chapter 15, 2012). Similar observations were also made in Sarada and Varaha Estuarine confluent point (Vijaya Pratap and Ramesh Babu, 2015).

\section{References}

Ajithkumar, T.T., Thangaradjou, T. and Kannan, L. 2006. Physico-chemical and biological properties of the Muthupettai mangrove in Tamil Nadu. J. Mar. Biol. Ass. India, 48: 131-138.

Arthur, R. 2000. Coral bleaching and mortality in three Indian reef regions during an El Nino Southern oscillation event. Curr. Sci., 79: 12.

Arumugam and Sugirtha, P. Kumar. 2014. Evaluation of physico-chemical parameters and nutrients in the Mangrove ecosystem of manakudy Estuary, southwest coast of India. International Journal of Latest Research in Science and Technology, 3 (6): 205209.

Asha, P.S. and Diwakar, R. 2007. Hydrobiology of the inshore waters off Tuticorin in the Gulf. J. Mar. Biol. Ass. India, 49: 7-11.
Ashok Prabu, V., Rajkumar, M. and Perumal, P. 2008. Seasonal variations in Physicochemical characteristics of Pichavaram mangroves, southeast coast of India. J. Environ. Biol., 29: 945- 950.

Balasubramanian, R. and Kannan, L. 2005.Physico-chemical characteristics of the coral reef Environs of the Gulf of Mannar Biosphere Reserve, India. Int. J. Ecol. Environ. Sci., 31: 265-271.

Das, J., Das, S.N. and Sahoo, R.K. 1997. Semidiurnal variation of some physic chemical parameters in the Mahanadi estuary, East coast of India. Indian J. Mar. Sci., 26: 323-326.

Desai, P. 1992. Coastal environment of Gujarat: special reference to the Gulf of Kachchh (Remote sensing application mission) coastal environment space application centre (ISRO) Ahmedabad. Pp.129-146.

Dyer, K.R. 1986. Coastal and estuarine sediment dynamic, John Wiley \& sons, New York 342, pp.

Gadhia, M., Surana, R. and Ansari, E. 2012. Seasonal variations in physico-chemical characterstics of Tapi estuary in Hazira industrial area. Our Nature, 10: 249257.

Govindasamy, C., Kannan, L. and Jayapaul, A. 2000. Seasonal variation in physicochemical properties and primary production in the coastal water biotopes of Coromandel Coast, India. J. Environ. Biol., 21: 17.

Gowda, G., Rajesh, K.M. and Mridula, R.M. 2009. Mridula Vertical distribution of polychaetes in brackishwater pond of Nethravathi estuary, India. J. Environ. Biol., 30: 1025-1029.

Pillay, S., Lindsay, P., Lutchmiah, S. and Gengan, R.M. 2003. Morphology and sediment dynamics of the ephemeral Mfolozi estuary, KZN, South Africa. South African Geographical Journal, 85 (2): 158-163. 
Pravat Ranjan Dixit, Biswabandita Kar, Partha Chattopadhyay, Chitta Ranjan Panda. 2013. Seasonal Variation of the Physicochemical Properties of Water Samples in Mahanadi Estuary, East Coast of India. Journal of Environmental Protection. 4: 843-848. http://dx.doi.org/10.4236/jep.2013.4809 8.

Rajasegar, M. 2003. Physico-chemical characteristics of the Vellar estuary in relation to shrimp farming. J. Environ. Biol., 24: 95-101.

Santhosh Kumar, C. and Ashok Prabu, V. 2014. Physico-chemical parameters in Parangipettai coastal waters and Vellar estuary, Southeast coast of India. Int. J. Curr. Microbiol. App. Sci., 3(9) 85-93.

Saravanakumar, A., Rajkumar, M., Serebiah, J.S. and Thivakaran, G.A. 2008. Seasonal variations in physico-chemical characteristics of water, sediment and soil texture in arid zone mangroves of Kachchh-Gujarat. J. Environ. Biol., 29(5): 725-732.

Sobha Rani, 2016. Seasonal Changes in Physico-Chemical Characteristics of the Water of Gosthani Estuary in Visakhapatnam District-Andhra Pradesh, India. European Academic Research, 3(6): 12805-12814.

Sridhar, R., Thangaradjou, T., Senthil Kumar, S., Kannan, L. 2006. Water quality and phytoplankton characteristics in the
Palk Bay, Southeast coast of India. J. Environ. Biol., 27: 561566.

Sundaramanickam, A., Sivakumar, T., Kumaran, R., Ammaiappan, V. and Velappan, R. 2008. A comparative study of physico-chemical investigation along Parangipettai and Cuddalore coast. J. Env. Sci. and Tech., 1: 110.

Umamaheswara Rao, T., Nageswara Rao, I. and Sunakar Panda. 2015. Seasonal Variability and Behavior of Hydrographic and Nutrient Parameters in the Estuarine Waters of Gauthami Godavari, East Coast of India. IOSR Journal of Environmental Science, Toxicology and Food Technology (IOSR-JESTFT), 9 (11): 10-19.

Upadhyay. S. 1988.Physico-chemical characteristics of the Mahanadhi estuarine ecosystem. East coast of India. Ind. J. Mar. Sci., 17: 19-23.

Vijaya Pratap, G. and Ramesh Babu, K. 2015. Seasonal Variations of the PhysicoChemical Characteristics of Water Samples in Sarada and Varaha Estuarine Complex, East Coast of India. European Academic Research, 3(1): 472-486.

Voluntary estuary monitoring manual chapter 15, 2012. Turbidity and total solids available at http://www.epa.gov/owow/estuaries/mo nitor.

\section{How to cite this article:}

Kurma Rao, R. and Ramesh Babu, K. 2017. Seasonal Variations in Physico-Chemical Characteristics of Champavathi Estuary, East Coast of India. Int.J.Curr.Microbiol.App.Sci. 6(6): 443-447. doi: https://doi.org/10.20546/ijcmas.2017.606.051 